\author{
Tomasz Rachwal \\ Uniwersytet Pedagogiczny \\ im. Komisji Edukacji Narodowej \\ w Krakowie
}

\title{
Problematyka zmian w systemie emerytalnym w edukacji w zakresie przedsiębiorczości w szkole ponadgimnazjalnej
}

\author{
The issue of changes in the pension system in entrepreneurship education \\ in secondary school
}

\begin{abstract}
Streszczenie
Pod koniec 2013 r. w ekspresowym tempie wprowadzono nowe przepisy reformujące dotychczasowy system emerytalny w Polsce, prowadzące do praktycznej likwidacji II filaru oraz przejęcia przez państwo części środków zgromadzonych przez członków Otwartych Funduszy Emerytalnych (OFE). Wprowadzane zmiany są bardzo głębokie, co powoduje, że nowy system emerytalny w praktyce nie będzie już tym samym systemem, zaprojektowanym przez twórców wielkiej reformy z 1998 r. II filar staje się mało znaczącym elementem systemu emerytalnego, a dla wielu nie będzie w ogóle filarem emerytury. Celem tego artykułu jest więc prezentacja wprowadzanych zmian systemu emerytalnego, przedstawienie argumentów zwolenników i krytyków reformy oraz ich skutków dla obywateli i gospodarki krajowej w kontekście wprowadzania tych treści kształcenia przez nauczycieli na lekcjach podstaw przedsiębiorczości w szkole ponadgimnazjalnej.
\end{abstract}

\begin{abstract}
At the end of 2013 new legislation reforming the existing pension system in Poland, leading to the practical elimination of the second pillar and the takeover by the state of part of the funds collected by members of the open pension funds (OFE), was introduced at express pace. The changes are very deep, which means that the new pension system in practice will no longer be the same system, designed by the creators of the great reforms of the 1998. The second pillar becomes insignificant component of the pension system, and for many is not at all a pillar of retirement. The purpose of this article is therefore to present the changes in pension systems, presenting the arguments of supporters and critics of the reform and its implications for the citizens and the national economy in the context of the implementation of these teaching content by teachers in lessons on entrepreneurship in upper secondary school.
\end{abstract}

Słowa kluczowe: edukacja w zakresie przedsiębiorczości; Otwarte Fundusze Emerytalne; Polska; podstawy przedsiębiorczości; system emerytalny

Key words: basics of entrepreneurship; entrepreneurship education; pension funds; pension system; Poland

\section{Wprowadzenie}

Podstawa programowa przedmiotu podstawy przedsiębiorczości do szkół ponadgimnazjalnych (Rozporządzenie, 2008) przewiduje realizację treści kształcenia w zakresie przedsiębiorczości. W „treściach nauczania - wymaganiach szczegółowych” założono m.in., że uczeń ma umieć 
wyjaśnić rolę, jaką w gospodarce pełnią instytucje rynkowe takie jak: banki, giełda papierów wartościowych, fundusze inwestycyjne, firmy ubezpieczeniowe i fundusze emerytalne. Ponadto, po zakończeniu edukacji uczeń potrafi scharakteryzować system emerytalny w Polsce i wskazać związek pomiędzy swoją przyszłą aktywnością zawodową a wysokością emerytury oraz potrafi analizować oferty banków, funduszy inwestycyjnych, firm ubezpieczeniowych i funduszy emerytalnych. Podstawa programowa wyraźnie więc kładzie nacisk na zdobycie wiedzy i umiejętności związanych z uczestnictwem w II i III filarze systemu zabezpieczenia emerytalnego, w szczególności z wyborem Otwartych Funduszy Emerytalnych. Tymczasem pod koniec 2013 r. w ekspresowym tempie, na mocy naprędce uchwalonej przez Parlament i podpisanej bez zwłoki przez Prezydenta RP Ustawy z dnia 6 grudnia 2013 r. o zmianie niektórych ustaw $w$ zwiazku z określeniem zasad wypłaty emerytur ze środków zgromadzonych w otwartych funduszach emerytalnych (Dz.U. 2013 poz. 1717) ${ }^{1}$, wprowadzono nowe przepisy reformujące dotychczasowy system emerytalny w Polsce. Prowadzą one właściwie do likwidacji II filaru tego systemu oraz przejęcia przez państwo części środków zgromadzonych przez członków Otwartych Funduszy Emerytalnych (OFE). Wprowadzane zmiany są bardzo głębokie, co powoduje, że nowy system emerytalny w praktyce nie będzie już tym samym systemem, zaprojektowanym przez twórców wielkiej reformy z 1998 r. II filar, którym zgodnie z założeniami reformy miały być właśnie OFE, staje się praktycznie mało znaczącym elementem systemu emerytalnego, a dla wielu osób, które nie wybiorą opcji pozostania w II filarze, nie będzie w ogóle filarem emerytury.

Celem niniejszego artykułu jest więc prezentacja wprowadzanych zmian systemu emerytalnego na tle założeń tzw. wielkiej reformy z 1998 r., przedstawienie argumentów zwolenników i krytyków tych zmian oraz ich skutków dla obywateli i gospodarki krajowej w kontekście wprowadzania tych treści kształcenia przez nauczycieli na lekcjach podstaw przedsiębiorczości w szkole ponadgimnazjalnej. Edukacja w zakresie przedsiębiorczości wpływa na kształtowanie świadomości młodych ludzi, owocując w wielu obszarach życia jednostki - zarówno zawodowych, jak i prywatnych (Kosała, Pichur, 2008). Powinna jednocześnie nadążać za zmianami w uwarunkowaniach prawnych funkcjonowania społeczeństwa i gospodarki, a odpowiadać na współczesne wyzwania cywilizacyjno-gospodarcze (Wach, 2013). Przyjęto bowiem założenie, że problematyka ta jest bardzo ważna w kształceniu w zakresie przedsiębiorczości, na co wskazuje nie tylko podstawa programowa i propozycje jej rozszerzenia (Rachwał et al., 2008), lecz także programy nauczania przedmiotu „podstawy przedsiębiorczości” (np. Makieła, Rachwał, 2005; Nasłuchowski, 2012). Problematyka ta ważnie miejsce zajmuje także w podręcznikach szkolnych do podstaw przedsiębiorczości (por. Makieła, Rachwał, 2012). Powstaje więc problem, jak zmodyfikować dotychczasowe cele i treści kształcenia w tym zakresie, szczególnie w sytuacji ostrej krytyki i zarzutów niezgodności z konstytucją wprowadzanych zmian, co może w przyszłości skutkować cofnięciem niektórych z przyjętych

\footnotetext{
${ }^{1}$ Wymieniona ustawa zmieniła następujące, fundamentalne dla funkcjonowania systemu emerytalnego akty prawne: Ustawę z dnia 13 października 1998 r. o systemie ubezpieczeń społecznych (Dz.U. 1998 nr 137 poz. 887 z późn. zm.); Ustawę z dnia 28 sierpnia 1997 r. o organizacji i funkcjonowaniu funduszy emerytalnych (Dz.U. 1997 Nr 139 poz. 934 z późn. zm.); Ustawę z dnia 17 grudnia 1998 r. o emeryturach i rentach z Funduszu Ubezpieczeń Społecznych (Dz.U. 1998 Nr 162 poz. 1118 z późn. zm.); Ustawe z dnia 20 kwietnia 2004 r. o indywidualnych kontach emerytalnych (Dz.U. 2004 Nr 116 poz. 1205 z późn. zm.); Ustawe z dnia 21 listopada 2008 r. o emeryturach kapitałowych (Dz.U. 2008 Nr 228 poz. 1507 z późn. zm.),
} 
rozwiązań. Punktem wyjścia niezbędnym do realizacji celów kształcenia w tym zakresie jest poznanie przez uczniów dotychczasowego stanu funkcjonowania systemu emerytalnego, przyczyn podejmowanej reformy, w tym argumentów zwolenników i przeciwników reformy, a następnie skutków z perspektywy przeciętnego obywatela - osoby podlegającej systemowi przymusowego systemu zabezpieczenia emerytalnego. W artykule podjęto też próbę odpowiedzi na pytanie, jak należy traktować środki, które dotychczas trafiały do OFE, a obecnie trafiają na specjalne subkonto ZUS - czy są to jeszcze środki tzw. II filaru?

\section{Wielka reforma systemu emerytalnego z 1998 r. - podstawowe założenia}

Zrozumienie obecnych zmian wymaga przypomnienia, że do końca 1998 r. system emerytalny w Polsce opierał się na finansowaniu emerytur ze składek aktualnie pracujących osób i budżetu państwa, a więc był systemem repartycyjnym. W obliczu nowych wyzwań cywilizacyjnych, związanych głównie z procesem starzenia się społeczeństwa, a co za tym idzie wzrastających wydatków budżetowych na świadczenia emerytalne, podjęto decyzję o konieczności reformy tego systemu i zbudowaniu go, przynajmniej częściowo, na elementach mechanizmów kapitałowych.

W ramach tzw. czterech wielkich reform rządu Jerzego Buzka opracowano więc założenia nowego systemu. W efekcie od 1 stycznia 1999 r. system emerytalny w Polsce opiera się na trzech filarach:

- I filar stanowi Fundusz Ubezpieczeń Społecznych obsługiwany przez ZUS (składki są obowiązkowe);

- II filar to OFE (składki są obowiązkowe), zarządzane przez Powszechne Towarzystwa Emerytalne (PTE);

- III filar zakłada różne, indywidualne formy oszczędzania na emeryturę, np. w postaci Indywidualnych Kont Emerytalnych - IKE, Pracowniczych Programów Emerytalnych - PPE lub innych ubezpieczeń prywatnych (składki są dobrowolne).

Nowe prawo emerytalne wprowadziło więc podział na dwa źródła przyszłej emerytury: przyjęto założenie, że większa część świadczenia będzie pochodzić z systemu publicznego (ZUS), mniejsza zaś - z systemu prywatnego (Antonów, 1999). Środki zgromadzone w ramach I filaru nie są inwestowane, lecz zużywane na wypłacanie obecnych rent i emerytur. Natomiast środki zbierane w OFE (II filar) są pomnażane, czyli inwestowane w różne aktywa: papiery wartościowe dłużne (obligacje) i własnościowe (akcje).

Aktem prawnym, który reguluje działalność funduszy emerytalnych w Polsce, jest Ustawa z dnia 28 sierpnia 1997 roku - o organizacji i funkcjonowaniu funduszy emerytalnych, według której fundusz emerytalny jest osobą prawną, której przedmiotem działalności jest gromadzenie środków pieniężnych i ich lokowanie z przeznaczeniem na wypłatę członkom funduszu po osiągnięciu przez nich wieku emerytalnego. Organem funduszu jest towarzystwo emerytalne, które tworzy fundusz, zarządza nim oraz reprezentuje go na zewnątrz. Aktywa funduszu emerytalnego powstają w wyniku wpłacania do niego składek, pomniejszone o zobowiązania funduszu tworzą aktywa netto funduszu emerytalnego (Treippner, 2010).

W wypadku II filaru oszczędności członków OFE z czasem powinny więc zwiększać swoją wartość. Niestety, doświadczenie pokazało, że szczególnie w okresie kryzysu gospodarczego stopa zwrotu z inwestycji OFE jest dosyć niska, porównywalna ze stopą zwrotu z obligacji skarbowych (tab. 1.) czy z wyżej oprocentowanymi lokatami bankowymi. 
Tab. 1. Średnioroczne zyski OFE na tle wybranych inwestycji w latach 1999-2012

\begin{tabular}{|l|c|}
\hline \multicolumn{1}{|c|}{ Rodzaj inwestycji } & Średnioroczny zysk \\
\hline OFE (po uwzględnieniu wszystkich pobranych opłat) & $6,6 \%$ \\
\hline $\begin{array}{l}\text { ZUS (wysokość średniorocznej waloryzacji środków zgromadzonych na } \\
\text { indywidualnym koncie ZUS) }\end{array}$ & $6,8 \%$ \\
\hline $\begin{array}{l}\text { ZUS (wysokość średniorocznej waloryzacji środków zgromadzonych na } \\
\text { subkoncie) }\end{array}$ & $8,5 \%$ \\
\hline $\begin{array}{l}\text { Fundusz Rezerwy Demograficznej zarządzany przez ZUS (średnioroczna } \\
\text { stopa zwrotu) }\end{array}$ & $7,2 \%$ \\
\hline WIG (średnioroczny wzrost wartości indeksu) & $7,7 \%$ \\
\hline 5-letnie obligacje & $6,9 \%$ \\
\hline 10-letnie obligacje & $6,7 \%$ \\
\hline
\end{tabular}

Źródło: opracowanie własne na podstawie danych MPiPS.

Przy czym należy zwrócić uwagę, że wyniki te są zróżnicowane dla poszczególnych OFE, co wynika z danych za ostatnie trzy lata (tab. 2.). Warto jednak podkreślić za A. Strzelczyk (2012), że przy wyborze OFE należy kierować się więcej niż jednym rankingiem porównującym OFE.

Tab. 2. Trzyletnie stopy zwrotu* OFE wg Komisji Nadzoru

Finansowego za okres 30.09.2010-30.09.2013

\begin{tabular}{|c|c|}
\hline Nazwa OFE & Stopa zwrotu \\
\hline Nordea OFE & $23,019 \%$ \\
\hline Allianz Polska OFE & $21,137 \%$ \\
\hline ING OFE & $21,094 \%$ \\
\hline OFE WARTA & $20,430 \%$ \\
\hline Amplico OFE & $20,400 \%$ \\
\hline PKO BP Bankowy OFE & $20,276 \%$ \\
\hline Aviva OFE Aviva BZ WBK & $19,756 \%$ \\
\hline AXA OFE & $18,849 \%$ \\
\hline Pekao OFE & $18,787 \%$ \\
\hline OFE PZU „Złota Jesień” & $18,628 \%$ \\
\hline Generali OFE & $18,258 \%$ \\
\hline OFE Pocztylion & $17,449 \%$ \\
\hline AEGON OFE & $17,337 \%$ \\
\hline Średnia ważona stopa zwrotu & $19,751 \%$ \\
\hline
\end{tabular}

* Stopa zwrotu - zmiana wartości jednostki rozrachunkowej funduszu emerytalnego w określonym czasie.

Źródło: opracowanie własne na podstawie danych Komisji Nadzoru Finansowego.

Zgodnie z założeniami nowego systemu wysokość przyszłej emerytury zależy więc od:

- wysokości kapitału zgromadzonego w okresie aktywności zawodowej zarówno w I, jak i w II filarze;

- wieku przejścia na emeryturę - ponieważ im dłużej pracujemy, tym większy gromadzimy kapitał i krócej będzie on wypłacany w formie świadczenia emerytalnego. 
Skutkiem reformy z 1998 r. jest sytuacja, w której wysokość emerytury z I i II filaru będzie w świetle szacunków większości wypadków wynosić tylko 30-50\% ostatniego wynagrodzenia ubezpieczonego ${ }^{2}$. Celem reformy było więc stworzenie systemu emerytalnego, który umożliwiałby w przyszłości wypłatę świadczeń powiększającej się rzeszy emerytów oraz zachęcał do dłuższej pracy, a tym samym do dłuższego płacenia składek emerytalnych. Osiągnięto to m.in. dzięki uzależnieniu wysokości emerytury od stanu środków zgromadzonych na kontach w ZUS i OFE. Zgodnie z założeniami reformy oparcie systemu emerytalnego na trzech filarach miało zdywersyfikować ryzyko dla przyszłych emerytów. Wypłata części ich emerytur miała być zagwarantowana przez aktywa zgromadzone w OFE, dzięki czemu miały zmniejszyć się zobowiązania emerytalne państwa, finansowane z przyszłych składek lub podatków.

\section{Modyfikacje systemu emerytalnego do 2013 r.}

Wprowadzona w 1999 r. reforma pod pewnymi względami okazała się niedoskonała, a wg niektórych badaczy, m.in. L. Oręziak (2004), od początku była dużym błędem. Stopa zwrotu OFE jest stosunkowo niska. Wynika to z faktu, że inwestowały one dosyć ostrożnie, głównie w obligacje skarbowe, a inwestycje w akcje w sytuacji bessy na giełdzie nie przynosiły dobrych rezultatów. Warto jednak zwrócić uwagę, za R. Trzopem (2011), że ogólna ocena przyszłej efektywności pomnażania składki w II filarze jest zadaniem trudnym, ale dotychczasowe zachowanie się stóp zwrotu może być pomocniczym narzędziem takiego prognozowania. Zdaniem tego autora, OFE skuteczniej niż I filar (czyli stopy waloryzacji indywidualnego konta w ZUS) pomnażały powierzone im kapitały aż do czasu globalnego kryzysu w 2007 r. Zakładając, że negatywne zjawiska gospodarcze na taką skalę występują raz na kilkadziesiąt lat, można z dużym prawdopodobieństwem przypuszczać, że w stosunkowo krótkim czasie zarządzający aktywami OFE odrobiliby obecną różnicę w stopie zwrotu do I filara i ponownie stopy zwrotu OFE zaczną ją przewyższać (Trzop, 2011). Stosunkowo niska stopa zwrotu OFE wynika także z faktu, że pobierają one dosyć wysoką prowizję od kwot przekazywanych z ZUS i inwestowanych środków ${ }^{3}$. Eksperci dopatrują się źródła tego problemu w braku mechanizmu ścisłego powiązania wynagrodzeń OFE z osiąganymi zyskami. OFE bowiem zarabiają głównie na prowizjach od wpłacanych środków (w latach 1999-2012 wartość prowizji pobranych od przyszłych emerytów przez OFE wyniosła ok. $10 \mathrm{mld}$ zł, a łączna wartość wszystkich opłat: 17 mld zł), a nie od realnych zysków, czyli od osiąganych wyników. Kolejne zmiany w funkcjonowaniu tego systemu polegały więc na zmniejszaniu maksymalnej prowizji pobieranej przez OFE, z początkowych $10 \%$ do 3,5\%, z czego 0,8\% przejmuje ZUS jako koszty zbierania i przekazywania składek (ryc. 1). Jednocześnie podjęto decyzję o marginalizowaniu znaczenia OFE jako II filaru przez przesunięcie części składek do ZUS. I tak od maja $2011 \mathrm{r}$. z 19,52\% składki emerytalnej aż 17,22\% trafiało do ZUS, z czego 5\% (a od 2013 r. 4,5\%) na specjalne subkonto. Te 5\% (4,5\%) stanowi część składki wpływającej wcześniej do OFE, gdyż od maja 2011 r. już nie 7,3\%, ale 2,3\% (2,8\% od 2013 r.) podstawy wynagrodzenia pracownika jest przekazywane do OFE.

\footnotetext{
${ }^{2} \mathrm{Na}$ marginesie, należy zwrócić uwagę na niezbyt fortunne określanie przez ZUS osób podlegających ubezpieczeniu emerytalnemu, gdyż nie mamy tu do czynienia z dobrowolną umową ubezpieczeniową, ale z przymusowym systemem zabezpieczenia emerytalnego, w której nie jesteśmy stroną umowy mającą wpływ na jej kształt. Dla celów edukacyjnych warto więc rozróżniać te dwie sytuacje i w odniesieniu to tzw. ubezpieczeń społecznych (w tym emerytalnych) należy używać raczej sformułowania system zabezpieczenia społecznego.

${ }^{3}$ Więcej o wpływie różnego typu opłat na zgromadzone oszczędności emerytalne w pracy A. Sołdka (2011). Dzięki regularnie napływającym, obowiązkowym opłatom PTE mają stosunkowo stabilną sytuację finansową, w tym dobrą płynność finansową i wysoką stopę rentowności, i nawet zawirowania na rynkach finansowych nie są czynnikami mogącymi na nią wpłynąć (Trippner, 2010).
} 
Ryc. 1. Średnia wysokość prowizji (opłaty dystrybucyjnej) pobieranej od składki przez OFE w latach 2000-2012

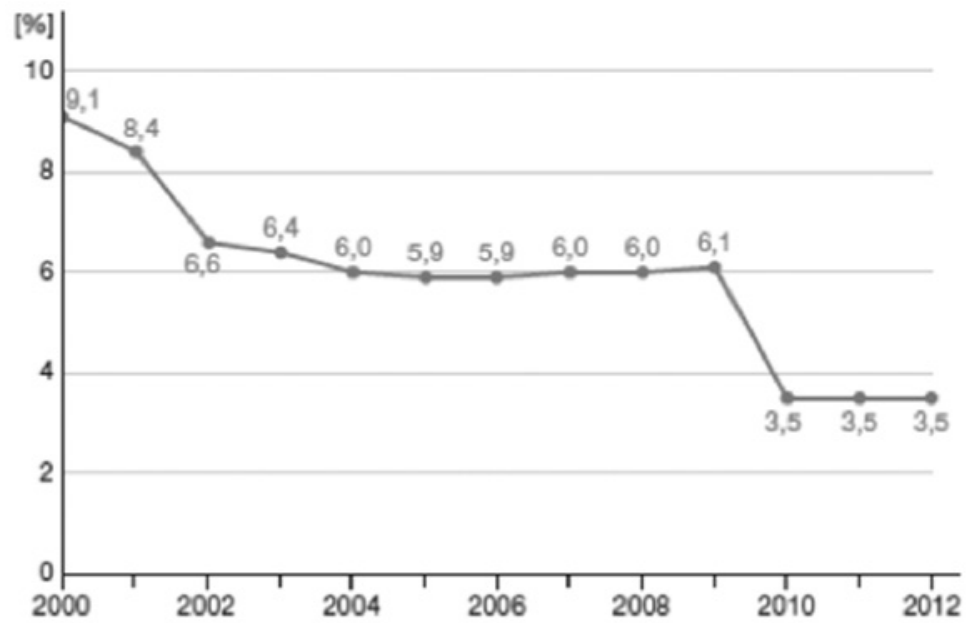

Źródło: opracowanie własne na podstawie informacji z MPiPS i MF.

W latach 1999-2011 OFE odgrywały dużą rolę w polskim systemie finansowym, ponieważ dysponowały ogromnymi środkami na inwestycje. Z czasem ich rola zaczęła się zmniejszać ze względu na mniejszy napływ nowych środków. Jednocześnie nastąpił proces łączenia się OFE - najmniejsze pod względem zgromadzonych aktywów i najsłabsze pod względem uzyskiwanych dochodów były przejmowane przez większe lub łączyły się, przy czym zmiany te wynikały też często z fuzji instytucji finansowych zarządzających OFE. W efekcie ich liczba spadła z 21 w 1999 r. do 13 w 2013 r.

\section{Wielka zmiana od 2014 r. - demontaż dotychczasowego systemu?}

Już reforma z 2011 r., kiedy to znacząca część składki emerytalnej została przesunięta z OFE do ZUS, została uznana przez wielu ekspertów i twórców reformy z 1998 r. za demontaż nowego systemu emerytalnego. Jednak dopiero decyzje z końca 2013 r., obowiązujące od tego roku, których efektem jest przeniesienie z OFE do ZUS ponad połowy aktywów oraz możliwość całkowitej (w dodatku domyślnej) rezygnacji z OFE, spowodowały istotną zmianę systemu. Od 2014 r. II filar stał się mało znaczącym elementem systemu emerytalnego, a dla wielu osób nie będzie w ogóle filarem emerytury. Wynika to z faktu, że nie jest on już obowiązkowy, a szereg rozwiązań szczegółowych, takich jak konieczność złożenia deklaracji o pozostaniu w OFE i zakaz reklamy OFE do końca lipca 2014 r., spowoduje, że wiele osób nie będzie już uczestnikami II filara systemu emerytalnego (szczegółowo zmiany przedstawiono w tab. 3).

Warto przy tym zwrócić uwagę, że choć w materiałach rządowych dotyczących reformy środki na subkoncie ZUS traktowane są nadal jako element II filaru (m.in. ze względu na ich dziedziczność), nie ma podstaw do takiego ich traktowania, gdyż jest to sprzeczne z ideą II filaru jako elementu kapitałowego systemu emerytalnego, w którym środki osób objętych ubezpieczeniem emerytalnym są inwestowane przez OFE, zgodnie z pierwotnymi założeniami reformy z 1999 r. Wydaje się więc słuszne przyjęcie założenia, szczególnie na potrzeby edukacyjne, że środki na subkoncie ZUS są elementem I, a nie II filaru, bo nie należą do OFE, nie są jako środki każdego ubezpieczonego inwestowane na rynku kapitałowym, a jedynie waloryzowane. 
Tab. 3. Zestawienie zmian w nowym systemie emerytalnym

\begin{tabular}{|c|c|}
\hline $\begin{array}{l}\text { Punkt wyjścio- } \\
\text { wy (1999) }\end{array}$ & $\begin{array}{l}\text { - trzy, w miarę równe pod względem znaczenia, filary systemu emerytalnego } \\
\text { (w praktyce III filar okazał się najsłabszym elementem konstrukcji ze względu } \\
\text { na małe zainteresowanie dobrowolnymi ubezpieczeniami) } \\
\text { - składka emerytalna wynosi } 19,52 \% \text {, w tym ponad } 1 / 3, \text { tj. } 7,3 \% \text { podstawy wymiaru, } \\
\text { wpływa do OFE } \\
\text { - prowizja dla OFE, tzw. opłata dystrybucyjna, jest pobierana od składki - jej } \\
\text { potrącenie następuje przed przeliczeniem składki na jednostki rozrachunkowe, a jej } \\
\text { wysokość nie może przekroczyć } 10 \% \text { (w wyniku konkurencji były one z reguły } \\
\text { nieco niższe, szczególnie dla klientów z dłuższym stażem w OFE) } \\
\text { - OFE pobierają dodatkowe opłaty, m.in. za zarządzanie aktywami czy za dokonanie } \\
\text { wypłaty transferowej (opłata jest pobierana w wyniku decyzji członka o przeniesie- } \\
\text { niu środków do innego otwartego funduszu) } \\
\text { - możliwość inwestowania przez OFE w szeroką gamę papierów wartościowych, } \\
\text { w tym polskie obligacje skarbowe } \\
\text { - brak decyzji odnośnie mechanizmu wypłat emerytur z II filara (OFE lub ZUS) }\end{array}$ \\
\hline $\begin{array}{l}\text { Zmiany } \\
\text { do } 2013 \mathrm{r} \text {. }\end{array}$ & $\begin{array}{l}\text { - znaczące zmniejszenie roli II filara przez zmiany proporcji wpływów do OFE } \\
\text { - przy } 19,52 \% \text { wysokości składki emerytalnej tylko 2,3\% (2,8\% od } 2013 \text { r.) } \\
\text { to środki do inwestowania przez OFE } \\
\text { - próby zwiększania zainteresowania inwestycjami w III filarze przez niewielkie } \\
\text { zachęty podatkowe dla osób inwestujących w PPE i IKE } \\
\text { - obniżenie maksymalnej prowizji pobieranej przez OFE do 7\%, a od } 2010 \mathrm{r} \text {. } \\
\text { do 3,5\% wartości przekazywanych składek (w tym prowizja dla ZUS: } 0,8 \%) \\
\text { - zniesienie od maja } 2011 \text { r. opłat za zmianę OFE } \\
\text { - podjęcie decyzji o stopniowym, wieloletnim procesie wydłużenia wieku emerytal- } \\
\text { nego dla kobiet i mężczyzn do } 67 \text { lat (jest on podnoszony od } 2013 \text { r. - co cztery } \\
\text { miesiące o jeden miesiąc; w efekcie poziom } 67 \text { lat dla mężczyzn zostanie osiągnię- } \\
\text { ty w } 2020 \text { r., a dla kobiet - w } 2040 \text { r.) }\end{array}$ \\
\hline $\begin{array}{l}\text { Stan obecny } \\
\text { (po zmianach } \\
\text { obowiązują- } \\
\text { cych od } \\
1.02 .2014 \text { r.) }\end{array}$ & $\begin{array}{l}\text { - marginalizacja roli OFE przez przejęcie 51,5\% aktywów zainwestowanych } \\
\text { w obligacje skarbowe (jest to tzw. umorzenie) oraz obligacje gwarantowane przez } \\
\text { Skarb Państwa (które będą stopniowo sprzedawane), a także gotówki } \\
\text { - likwidacja II filaru jako obowiązkowego elementu systemu emerytalnego: } \\
\text { umożliwienie pozostania w OFE w ramach II filaru lub przejścia do ZUS (brak } \\
\text { deklaracji do końca lipca } 2014 \text { oznacza rezygnację z OFE); zmiana decyzji będzie } \\
\text { możliwa w } 2016 \text { r. i następnie co cztery lata - zawsze od } 1 \text { kwietnia do } 31 \text { lipca } \\
\text { - wprowadzenie zakazu reklamy OFE do końca lipca } 2014 \text { r. } \\
\text { - składka emerytalna wynosi 19,52\%, w wypadku wyboru OFE: 2,92\% (czyli 1/7) } \\
\text { wpłynie do funduszu, a reszta (6/7) do ZUS, w tym 4,38\% na specjalne subkonto } \\
\text { - } 10 \text { lat przed osiągnięciem wieku emerytalnego środki z OFE mają być stopniowo } \\
\text { przenoszone na fundusz emerytalny FUS i ewidencjonowane na prowadzonym } \\
\text { przez ZUS subkoncie (tzw. suwak bezpieczeństwa); wypłatą emerytur będzie } \\
\text { zajmował się ZUS } \\
\text { - wprowadzenie zakazu inwestowania przez OFE w instrumenty (papiery wartościo- } \\
\text { we) dłużne skarbowe lub gwarantowane przez Skarb Państwa, np. polskie obligacje } \\
\text { skarbowe } \\
\text { - ustalenie minimalnego limitu inwestowania w akcje (do końca } 2014 \text { r. będzie } \\
\text { on wynosił 75\% i w kolejnych latach stopniowo będzie maleć, aż w } 2018 \text { r. } \\
\text { zniknie) } \\
\text { - obniżenie maksymalnej prowizji dla OFE do 1,75\% wartości przekazywanych } \\
\text { składek (w tym prowizja dla ZUS: 0,4\%) }\end{array}$ \\
\hline
\end{tabular}

Źródło: opracowanie własne. 
Zarówno zwolennicy, jak i krytycy wprowadzanych zmian przyznają więc, że doszło do całkowitego odwrócenia reformy rządu J. Buzka wprowadzającej nowy system emerytalny od 1999 r. Różne są jednak opinie odnośnie przesłanek wprowadzanych zmian, ich zgodności z konstytucją, jak i dalszych konsekwencji.

\section{Zalety i wady wprowadzanych zmian}

Analizy materiałów rządowych promujących reformę oraz wypowiedzi ekspertów uważających zmiany za korzystne dla gospodarki Polski oraz obecnych i przyszłych emerytów wskazują na następujące argumenty za wprowadzeniem reformy ${ }^{4}$ :

- OFE nie sprawdziły się jako instytucje dobrze inwestujące środki przyszłych emerytów ze względu na niską stopę zwrotu ich znaczenie w przyszłej emeryturze byłoby zbyt małe;

- OFE zarabiały zbyt dużo na prowizjach, nie troszcząc się o jak najwyższe stopy zwrotu;

- OFE inwestowały znaczące środki w obligacje skarbu państwa, tym samym powiększając dług publiczny, a z punktu widzenia finansów państwa nie mają sensu transfery środków z ZUS do OFE po to, aby potem OFE je pożyczały państwu jako emitentowi obligacji skarbowych;

- inwestycje OFE w obligacje skarbowe, a nie w akcje, nie przyczyniają się do wzrostu gospodarczego i spadku bezrobocia;

- zmiany należy wprowadzić szybko ze względu na dobro finansów państwa, jak i przyszłych emerytów, których emerytury wypłacane z II filara są zagrożone ze względu na niską stopę zwrotu;

- umorzenie obligacji skarbu państwa znacznie zmniejszy dług publiczny i poprawi sytuację w ZUS związaną z brakiem środków na wypłaty dla obecnych emerytów;

- pieniądze w ZUS będą bezpieczniejsze niż w OFE, co ma duże znaczenie z punktu widzenia przeciętnego obywatela, który woli pewną, bo gwarantowaną przez budżet państwa, emeryturę z ZUS;

- przeciętny Polak jest zbyt biedny na inwestycje w emerytury kapitałowe, o czym świadczy małe zainteresowanie III filarem, dlatego należy przywrócić pełną odpowiedzialność państwa za wypłatę emerytur;

- aktywa OFE należą do państwa (nie są środkami przyszłych emerytów), dlatego może zrobić ono z nimi co chce, w zależności od aktualnych potrzeb budżetu państwa i sytuacji gospodarczej.

L. Oręziak (2014) zauważa także, że reforma emerytalna z 1999 r. została wprowadzona w Polsce pod naciskiem międzynarodowych instytucji finansowych, które zauważyły szansę wielkich zysków na dziesięciolecia z przymusowych filarów kapitałowych, dlatego też wg niej nie mogła być korzystna ani dla przyszłych emerytów, ani dla całego państwa. Konieczne jest więc szybkie jej odwrócenie, tj. likwidacja OFE. Trudno się jednak zgodzić z poglądami autorki, że najważniejszym problemem wynikającym z istnienia OFE jest wzrost zadłużenia państwa. Bezspornie OFE inwestowały znaczną część środków w obligacje skarbu państwa, ale powstaje pytanie o pierwotną przyczynę zadłużenia, tj. dlaczego państwo, pozwalając na zwiększanie się corocznie deficytu budżetowego, musiało emitować w takiej ilości obligacje? Trudno za ten fakt winić OFE, które po prostu inwestowały w instrumenty dostępne na rynku kapitałowym.

\footnotetext{
${ }^{4}$ Do głównych zwolenników reformy należy zaliczyć L. Oręziak, która w swojej pracy (2014) uważa, że wprowadzenie OFE było błędem i powinno się je jak najszybciej zlikwidować. Argumenty za i przeciw reformie od 2014 r. proponuje się wykorzystać na lekcji jako podsumowanie dyskusji uczniów na podstawie wcześniej wyszukiwanych przez nich informacji z wykorzystaniem internetu.
} 
Argumenty przeciwników reformy są następujące ${ }^{5}$ :

- obowiązkowy II filar jest niezbędnym elementem wprowadzonego w 1999 r. systemu emerytalnego, dywersyfikującym ryzyko wypłaty i wysokości przyszłych emerytur;

- szybkość wprowadzania zmian, konieczność składania deklaracji o chęci pozostania w OFE i zakaz ich reklamy świadczą o innych celach reformy niż dobro przyszłych emerytów, a więc chęci zmniejszenia „na papierze” długu publicznego i poprawie kondycji finansowej ZUS;

- choć w wyniku reformy obniży się dług jawny, nadal pozostanie wysoki dług ukryty (czyli zobowiązania przyszłe wobec emerytów), sytuacja poprawi się więc tylko chwilowo, a z punktu widzenia długoterminowego taka operacja finansowa jest bezcelowa;

- zmniejszenie długu jawnego, a więc pozorny jego spadek, spowoduje większą skłonność rządu (i ewentualnie kolejnych rządów) do dalszego zadłużania państwa;

- efektywność OFE w pomnażaniu środków przyszłych emerytów jest na dobrym poziomie w porównaniu z innymi możliwościami oszczędzania, a inwestowanie przez nie, także w obligacje skarbowe, jest niezbędnym elementem strategii inwestycyjnej tego typu instytucji finansowych (zakazywanie funduszowi kapitałowemu inwestowania w obligacje jest kuriozalne);

- choć OFE nie notują rekordowych zysków z inwestycji, to nieprawdziwe są obawy przed niskimi zyskami - w długim okresie, a na emeryturę oszczędzamy przez kilkadziesiąt lat, zdywersyfikowany portfel akcji i obligacji, w który inwestują OFE, pozwala stosunkowo dobrze zarobić; wskazuje na to historia rynków finansowych;

- pieniądze w ZUS nie będą bezpieczniejsze niż w OFE, ponieważ w większości są tylko wirtualne, istnieją na papierze, a nie w postaci realnych inwestycji;

- przeciętny obywatel nie może być pewny emerytury z ZUS, ponieważ zasady ich wypłaty mogą być w każdej chwili zmienione, w zależności od potrzeb budżetu państwa, a w OFE ich gromadzenie, pomnażanie i późniejsza wypłata była prawnie chroniona (fundusz to osobna osoba prawna);

- koszty obsługi i inwestowania składek przez ZUS są porównywalne, a nawet wyższe od kosztów prowizji dla OFE, szczególnie po jej obniżce (prowizja pobierana przez OFE, zgodnie ze znowelizowaną ustawą, wynosi tylko $1,75 \%$, natomiast prowizja zwrotna płacona przez OFE dla ZUS wynosi 0,4\%, co oznacza, że rzeczywista prowizja funduszy wyniesie zaledwie 1,35\%);

- podjęte zmiany są niekonstytucyjne, aktywa OFE nie należą do państwa ${ }^{6}$, ale są własnością prywatną, czyli należą do przyszłych emerytów, dlatego rząd nie może ich tak po prostu zabrać i przekazać do ZUS.

\section{Wątpliwości konstytucyjne}

Choć Prezydent RP Bronisław Komorowski podpisał, zgodnie z wolą rządu bez zbędnej zwłoki, ustawę wprowadzającą te reformy 27 grudnia 2013 r., to jednocześnie skierował do Trybunału Konstytucyjnego (TK) wniosek o zbadanie, czy jest ona zgodna z ustawą zasadniczą. Wątpliwości Prezydenta RP dotyczą m.in. zakazu inwestowania w obligacje skarbowe i nakazu - określonego czasowo i procentowo - inwestowania środków OFE w akcje oraz zakazu reklamy OFE i związanych z tym kar za ewentualne naruszenie zakazu. Jednak zdaniem ekspertów wniosek Prezydenta do TK ws. OFE nie odnosi się do meritum sprawy (por.

\footnotetext{
${ }^{5}$ Do głównych przeciwników reformy należy zaliczyć b. prezesa NBP i wicepremiera i ministra finansów w rządzie T. Mazowieckiego, prof. L. Balcerowicza, którego liczne wypowiedzi na ten temat można znaleźć w internecie, m.in. na stronie Forum Obywatelskiego Rozwoju (www.for.org.pl).

${ }^{6}$ Jak uważają zwolennicy likwidacji OFE, np. wspomniana już L. Oręziak, wg której ta część składki emerytalnej powinna trafiać nie do OFE, ale na wypłatę bieżących emerytur.
} 
PAP, 2014). Nie dotyczy bowiem fundamentalnej kwestii, jaką jest charakter (publiczny bądź prywatny członków funduszy) środków zgromadzonych w OFE, a więc, czy mieliśmy do czynienia z wywłaszczeniem, czy nie. Nawet gdyby - przyjmując hipotetycznie - TK uznał niekonstytucyjność wszystkich zakwestionowanych przez Prezydenta RP zapisów ustawy, to wówczas OFE nadal mogłyby kupować obligacje skarbu państwa, mogłyby inwestować według przyjętych przez siebie strategii i mogłyby się reklamować, ale to niekoniecznie oznacza podstawę do podważenia najważniejszych decyzji, które zostały podjęte, czyli w szczególności tych związanych z przeniesieniem ponad połowy aktywów OFE do ZUS (PAP, 2014). Wątpliwości budzi także skierowane do rządu zapytanie Prezesa TK, w którym prosi o przedstawienie informacji, jakie koszty poniósłby budżet w wypadku stwierdzenia niekonstytucyjności zapisów ustawy o zmianach w OFE. Zgodnie z zapowiedzią Premiera rząd przedstawi takie wyliczenia, ale już ze wstępnych obliczeń wiadomo, że będzie to kwota ogromna. Wątpliwości wobec tego zapytania związane są z podejrzeniem, że wyrok TK może uwzględniać nie tylko zgodność zmian z Konstytucją, do czego TK jest powołany, lecz także skutki potencjalnie możliwego negatywnego wyroku dla rządu. Wątpliwości te umacniają przeciwników reformy w przekonaniu, że tak naprawdę nie chodzi o dobro emerytów, ale o bieżące potrzeby finansowe budżetu państwa.

\section{Co dalej z systemem emerytalnym? - skutki dla OFE i obywateli}

W wyniku reformy następuje demontaż dotychczasowego systemu emerytalnego. II filar powoli przestaje istnieć, nawet jeśli część Polaków zdecyduje się na pozostanie w OFE. Trudno bowiem za środki inwestowane w ramach drugiego filaru uznać subkonto w ZUS. W wypadku małego zainteresowania pozostaniem w OFE lub słabych wyników finansowych oraz w warunkach konieczności inwestowania w akcje w czasach niepokojów na rynkach finansowych i słabej koniunktury na GPW, rządzący dostaną dobry argument do ręki, że OFE należy całkowicie zlikwidować. Co prawda taka decyzja może grozić procesami odszkodowawczymi ze strony instytucji finansowych, które powołały PTE i podjęły się zarządzania OFE, niemniej jest wielce prawdopodobne, że zostanie ona podjęta. Podobne wątpliwości były związane $\mathrm{z}$ umorzeniem ponad połowy aktywów OFE i zabraniem ich do ZUS, a jednak ustawa została przegłosowana. Przy czym wyrok TK o niezgodności z Konstytucją wprowadzonych zmian może wpłynąć na zatrzymanie dalszego demontażu systemu, szczególnie jeśli zostanie zakwestionowany zakaz kupna obligacji i nakaz inwestowania w akcje.

Jest niemal pewne, że w wyniku zmniejszania wartości aktywów i przy mniejszym napływie środków w przyszłości nastąpią procesy konsolidacji OFE, tak że na rynku pozostanie tylko kilka z nich. Powstaje jednak pytanie, czy nie zniknie wtedy całkowicie (już teraz mocno ograniczona) konkurencja między nimi. Jest ona korzystna dla przyszłych emerytów, ponieważ OFE starają się o nich walczyć. Brak realnej konkurencji może oznaczać niższe stopy zwrotu.

Dla obywateli - uczestników przymusowego systemu emerytalnego - wprowadzona reforma oznacza, że ich przyszła emerytura będzie w całkowitym lub dużo większym stopniu zależała od wskaźników waloryzacyjnych stosowanych przez ZUS, a nie od wyników wypracowanych inwestycji. Chęć pozostania w OFE należy jednak zgłosić w nieprzekraczalnym terminie do końca lipca 2013 r. Brak takiego zgłoszenia oznacza, że całość emerytury będzie pochodzić z ZUS. Zmiana decyzji będzie możliwa dopiero za dwa lata, a następnie co cztery lata.

Co prawda w wyniku reformy nieznacznie zwiększono część składki pozostałej w OFE (z 2,3\% do 2,92\%, choć pierwotnie było to 7,3\%), ale jednocześnie rząd, przejmując środki z OFE, skrócił proces oszczędzania z prawie 60 do mniej więcej 30-35 lat, co oznacza, że mniejsze będą zyski kapitałowe. Zmiana ta wynika z faktu, że na 10 lat przed emeryturą środki zgromadzone w OFE mają być transferowane do ZUS, nie będą więc inwestowane przez OFE, także po rozpoczęciu wypłacania emerytury, jak to było pierwotnie zakładane. 
Część ekspertów zwraca też uwagę, że reforma jest niebezpieczna dla państwa i emerytów. Emerytura z ZUS zależy od rozwoju gospodarki i liczby osób pracujących. Jak wskazują prognozy demograficzne, liczba pracujących będzie się zmniejszała, a rząd przyjął założenie, że waloryzacja emerytur z ZUS będzie zawsze dodatnia. Oznacza to, że będzie się pogłębiała nierówność pomiędzy wielkością wpłat i wypłat emerytur z ZUS. W efekcie w pewnym momencie rząd może stwierdzić, że budżet państwa nie jest w stanie tego udźwignąć i dlatego jest konieczne zmniejszenie wysokości wypłat. Może to oznaczać niższe emerytury dla obecnie pracujących. Należy mieć też świadomość, że przeciętna emerytura kobiet jest dużo niższa niż mężczyzn, co wynika głównie z krótszego okresu pracy.

\section{Uwagi końcowe}

Na zakończenie warto zauważyć, że całościowa i w miarę obiektywna ocena wprowadzonych zmian jest możliwa dopiero po dłuższym czasie. Na dzisiaj w perspektywie krótkookresowej, z punktu widzenia finansów państwa i osób przechodzących w najbliższym czasie na emerytury, wydaje się korzystna. W perspektywie długookresowej, z punktu widzenia przyszłych emerytów, nie wydaje się jednak dobrym rozwiązaniem, choć są gorący zwolennicy tezy, że właśnie w tej perspektywie będzie ona korzystna dla społeczeństwa (Oręziak, 2014). Nie zmienia to faktu, że z tymi ważnymi zmianami należy zapoznać uczniów szkół ponadgimnazjalnych - przyszłych uczestników systemu emerytalnego - jako pracowników, z których pensji pobierane będą składki na system zabezpieczenia społecznego oraz przyszłych emerytów - świadczeniobiorców tego systemu. Ze względu na gorącą dyskusję polityków oraz niejednoznaczną ocenę wprowadzanych zmian wśród ekspertów, proponuje się przeprowadzić lekcje odnoszące się do tej problematyki z wykorzystaniem metody dyskusji w różnych możliwych wariantach (debata „za i przeciw”, debata oksfordzka, dyskusja panelowa), należącej do grupy metod aktywizujących.

\section{Literatura \\ References}

Antonów, K. (1999), Otwarte fundusze emerytalne w systemie zabezpieczenia emerytalnego w Polsce, Praca i Zabezpieczenie Społeczne, 11, 10-15.

Kosała, M., Pichur, A. (2008). Analiza działań przedsiębiorczych i postrzeganie prowadzenia działalności gospodarczej przez młode pokolenie - wybrane aspekty. Przedsiębiorczość - Edukacja, 4, 357-364.

Makieła, Z., Rachwał, T. (2005). Podstawy przedsiębiorczości - program nauczania dla liceum ogólnoksztatcacego, liceum profilowanego i technikum, wydanie drugie, Warszawa: Nowa Era.

Makieła, Z., Rachwał, T. (2012). Krok w przedsiębiorczość - podręcznik do podstaw przedsiębiorczości dla szkót ponadgimnazjalnych, Warszawa: Nowa Era.

Niesłuchowski, M. (2012, data dostępu 1.04.2014). Program nauczania podstaw przedsiębiorczości w zakresie podstawowym dla szkót ponadgimnazjalnych - Krok w przedsiębiorczość, dokument elektroniczny dostępny na stronie internetowej: http://www.nowaera.pl/component/pomoce/27/pg/ podstawy-przedsiebiorczosci.html?idk $=9999997$.

Oręziak, L. (2014), OFE - katastrofa prywatyzacji emerytur w Polsce, Warszawa: Instytut Wydawniczy Książka i Prasa.

PAP (2014, data dostępu 1.04.2014). Dr Balicki: wniosek prezydenta do TK ws. OFE nie dotyczy meritum sporu, publikacja elektroniczna dostępna na stronie internetowej http://prawo.rp.pl/artykul/1087121.html.

Rachwał, T., Kudełko, J., Tracz, M., Wach, K., Kilar, W. (2008). Projekt podstawy programowej podstaw przedsiębiorczości w zakresie rozszerzonym dla liceum ogólnokształcącego, liceum profilowanego i technikum. Przedsiębiorczość - Edukacja, 4, 312-324.

Sołdek, A. (2011), Wpływ opłat na zgromadzone oszczędności emerytalne w regulowanych i dobrowolnych systemach, Polityka Spoleczna, 2011, numer specjalny, 38-43. 
Strzelczyk, A. (2012). Otwarte fundusze emerytalne - analiza taksonomiczna, Prace Naukowe Uniwersytetu Ekonomicznego w Katowicach, 2012, 342-359.

Trippner, P. (2010). Analiza płynności finansowej i rentowności Powszechnych Towarzystw Emerytalnych, Annales Universitatis Mariae Curie-Skłodowska. Sectio H. Oeconomia, 44/2, 969-980.

Trzop, R. (2011), Fundusze emerytalne na plusie, Gazeta Bankowa, 1, 55-61.

Ustawa z dnia 13 października 1998 r. o systemie ubezpieczeń społecznych (Dz.U. 1998 Nr 137 poz. 887 z późn. zm.).

Ustawa z dnia 17 grudnia 1998 r. o emeryturach i rentach z Funduszu Ubezpieczeń Społecznych (Dz.U. $1998 \mathrm{Nr} 162$ poz. 1118 z późn. zm.).

Ustawa z dnia 20 kwietnia 2004 r. o indywidualnych kontach emerytalnych (Dz.U. 2004 Nr 116 poz. 1205 z późn. zm.).

Ustawa z dnia 21 listopada 2008 r. o emeryturach kapitałowych (Dz.U. 2008 Nr 228 poz. 1507 z późn. zm.).

Ustawa z dnia 28 sierpnia 1997 r. o organizacji i funkcjonowaniu funduszy emerytalnych (Dz.U. 1997 $\mathrm{Nr} 139$ poz. 934 z późn. zm.).

Ustawa z dnia 6 grudnia 2013 r. o zmianie niektórych ustaw w zwiazku z określeniem zasad wypłaty emerytur ze środków zgromadzonych w otwartych funduszach emerytalnych (Dz.U. 2013 poz. 1717).

Wach, K. (2013). Edukacja na rzecz przedsiębiorczości wobec współczesnych wyzwań cywilizacyjno-gospodarczych. Przedsiębiorczość - Edukacja, 9, 246-257.

Tomasz Rachwal, dr, członek Krajowej Rady Przedsiębiorczości. Pełni m.in. funkcję Kierownika Zakładu Przedsiębiorczości i Gospodarki Przestrzennej Instytutu Geografii Uniwersytetu Pedagogicznego im. KEN w Krakowie, Sekretarza Naukowego Komisji Geografii Przemysłu Polskiego Towarzystwa Geograficznego, Zastępcy Redaktora Naczelnego czasopism: Przedsiębiorczość - Edukacja, Prace Komisji Geografii Przemystu Polskiego Towarzystwa Geograficznego, Annales Universitatis Paedagogicae Cracoviensis Studia Geographica oraz członka redakcji Entrepreneurial Business and Economics Review. Autor lub współautor podręczników szkolnych i akademickich z zakresu geografii ekonomicznej i przedsiębiorczości. Jego zainteresowania badawcze skupiają się przede wszystkim na problematyce przemian struktur przestrzennych przemysłu, funkcjonowania różnych branż działalności gospodarczej, restrukturyzacji przedsiębiorstw oraz roli przedsiębiorczości w rozwoju układów przestrzennych, a także edukacji w zakresie przedsiębiorczości.

Tomasz Rachwal, PhD, Pedagogical University of Cracow, Institute of Geography, Department of Entrepreneurship and Spatial Management.

Member of the National Council for Entrepreneurship. Head of Department of Entrepreneurship and Spatial Management of Institute of Geography of the Pedagogical University of Cracow, Scientific Secretary of the Industrial Geography Committee of the Polish Geographical Society, Deputy Editor in Chief of the following journals: Entrepreneurship-Education, Studies of the Industrial Geography Commission of the Polish Geographical Society, Annales Universitatis Paedagogicae Cracoviensis Studies Geographica, and member of the editorial board of Entrepreneurial Business and Economics Review. Author or co-author of school and academic textbooks on economic geography and entrepreneurship. His research interests focus primarily on the issue of change of spatial structures of industry, the functioning of various branches of industrial activity, corporate restructuring and the role of entrepreneurship in the development of spatial systems as well as entrepreneurship education.

Adres/Address: Uniwersytet Pedagogiczny im. Komisji Edukacji Narodowej w Krakowie Instytut Geografii, Zakład Przedsiębiorczości i Gospodarki Przestrzennej ul. Podchorążych 2, 30-084 Kraków, Polska, e-mail: T.Rachwal@up.krakow.pl 